\title{
Gene therapy with VEGF 165 for angiogenesis in experimental acute myocardial infarction
}

\author{
Terapia gênica com VEGF 165 para angiogênese no infarto agudo do miocárdio experimental
}

Roberto T. SANT'ANNA, Renato A. K. KALIL ${ }^{1}$, Paulo MORENO ${ }^{1}$, Luiz C. J. ANFLOR ${ }^{1}$, Daniel L.C. CORREA ${ }^{1}$, Roberto LUDWIG ${ }^{1}$, Marinez B. BARRA ${ }^{1}$, Eduardo A. SILVA ${ }^{2}$, Nance NARDI ${ }^{2}$, João Ricardo M. SANT'ANNA', Paulo R. PRATES ${ }^{1}$, Ivo A. NESRALLA ${ }^{1}$

RBCCV 44205-629

\begin{abstract}
Objective: Evaluate coronary angiogenic response to transmural injection of plasmid encoding VEGF 165 in acute myocardial infarction (AMI) zones in a canine model.

Methods: The heart of eleven dogs was exposed and AMI was induced by occlusion of the diagonal branch of anterior descending coronary artery. For each of 10 selected points in the infarction area and its peripheral zone injections of $1 \mathrm{ml}$ of saline solution (control group: five dogs) or $1 \mathrm{ml}$ of plasmid encoding VEGF 165 solution $(200 \mu \mathrm{g} / \mathrm{ml})$ (VEGF group: six dogs) were introduced. Tecnecium myocardial scintigraph was performed immediately after animal recovery and 14 days later to evaluate the myocardial perfusion. The animals were sacrificed and the hearts were submitted to a histological study of the infarcted area, peripheral zone and normal posterior ventricular wall, to evaluate the number of arterioles and capillaries.

Results: Immediate modifications in myocardial perfusion found in scintigraphic studies were similar in both groups. In the second evaluation at 14 days, hypoperfusion of ischemic
\end{abstract}

1 Instituto de Cardiologia do Rio Grande do Sul/Fundação Universitária de Cardiologia.

2 Genetics Department of the Federal University of Rio Grande do Sul.

Financial support: FAPERGS and CNPq

Cardiovascular Surgery Department of the Institute of Cardiology of Rio Grande do Sul/University Foundation of Cardiology

Genetic Department of the Federal University of Rio Grande do Sul - UFRGS

Correspondence address

Instituto de Cardiologia do Rio Grande do Sul / FUC

Unidade de Pesquisa - Dr. Roberto Tofani Sant'Anna

Av. Princesa Isabel, 370 Porto Alegre, RS, Brazil CEP: 90920-00

E-mail: pesquisa@cardnet.tche.br ou santanna $@$ cardiologia.org.br. area had recovered by $\mathbf{7 0} \%$ to $90 \%$ when compared to the day of AMI. Histologic evaluation of the peripheral area of AMI indicated a larger number of vessels in the VEGF group when compared to controls (mean: $123.81+21.48$ and $40+6.13$, $p<$ 0.01 , respectively). This increase resulted mainly from an increase in the number of capillaries $(97.5+16.04$ in the VEGF group and $22.18+3,25$ in control group, $p<0.01$ ), as the number of arterioles did not increase significantly. In the VEGF group, a comparison in the number of vessels of the AMI peripheral area and normal myocardium revealed a non-significant increase of vessels in the ischemic area $(123.81+21.48$ and $95.14+41.19)$.

Conclusion: An intramural injection of plasmid VEGF 165 resulted in a significant increase in the number of capillaries in the peripheral AMI area. This increase may have a beneficial effect in the reduction and recovery of the ischemic area secondary to AMI.

Descriptors: Gene therapy. Angiogenesis. VEGF. Acute myocardial infarction. 
Resumo

Objetivo: Verificar a induç̃o de angiogênese miocárdica pela injeção transmural de plasmídeo VEGF 165 (Genentech/ USA) em zonas do infarto agudo do miocárdio (IAM) de cães, mediante avaliação por cintilografia miocárdica e estudo histológico.

Métodos: Em onze cães anestesiados o coração foi abordado em toracotomia antero-lateral esquerda e produzido IAM pela ligadura simples de ramo diagonal da artéria coronária descendente anterior. Em cada de 10 pontos selecionados da área infartada e sua periferia foi realizada a injeção de um total de $1 \mathrm{ml}$ de solução salina (grupo controle: cinco cães) ou de solucão contendo plasmídeo VEGF 165 na concentração de $200 \mathrm{ug} / \mathrm{ml}$ (grupo tratado: seis cães). Os animais foram recuperados e realizada cintilografia miocárdica com Tecnécio imediatamente e 14 dias após IAM. Os animais foram sacrificados e o coração retirado para estudo histológico da área de infarto, de sua periferia e de área da pared ventricular posterior, visando contagem eletrônica de capilares e arteríolas

Resultados: Cintilografia mostrou modificações na perfusão miocárdica comparáveis entre os grupos quanto ao estudo imediato e 15 dias após IAM, sendo que os dois grupos

\section{INTRODUCTION}

Gene therapy represents a new treatment modality for coronary disease due to exogen angiogenic factors (or genes which codify these factors) to develop new arterial vessels or to promote the reshaping of the existing vessels [1]. This treatment is based on experimental studies of ischemia that demonstrate angiogenic interventions such as a form of improving the myocardial perfusion [2-5]. Angiogenic agents were efficacious both by direct trans-myocardial injection of nude plasmid DNA, as through viral vectors or liposomes. Trans-myocardial injection has the advantage of low potentiality in the generation of side effects and, depending on the form in which the transfection is performed, it is possible to use it as an adjuvant therapy in existing treatments.

Vascular endothelial growth factor (VEGF) is one of the most widely angiogenic agents studied $[2,6-8]$, partially because its mitogenic activity is specific for endothelial cells and its expression is induced by hypoxia, which denotes it to be a natural mediator in angiogenesis as a response to ischemia. More commonly, the protein is a polypeptide homodimer with 165 or 121 amino acids (VEGF165 and VEGF121), with both capable of improvements in the collateral blood flow in experimental models.

In an earlier study [9], we developed a canine model of ischemic heart disease with scintigraphic control and we tested the transfection of the gene responsible for the mostraram uma recuperação de 70 a 90 \% da hipoperfusão demonstrada no 10 exame. $O$ estudo histológico da área de transição do IAM revelou um maior número de vasos no grupo tratado em relação ao grupo controle (média de 123,8 $+21,48$ e $40+6,13$, respectivamente; $p<0,01)$. Este crescimento do número de vasos é atribuível principalmente ao aumento do número de capilares $(97,5+16,04$ no grupo tratado e $22,18+3,25$ no grupo controle, $p<0,01$ ), sendo que em relação ao número de arteríolas o aumento não fo significativo $(25,16+10,89$ e 16,8 + 4,75; NS). A comparação entre a região de transição do IAM do grupo tratado e de área normal, revelou um maior número de vasos na região tratada, ainda que a diferença não fosse significativa respectivamente $123,81+21,48$ e $95,14+41,19, p>0,05$ ).

Conclusões: Injeção transmural de plasmídeo VEGF 165 resultou em significativo aumento no número de capilares na zona de transição do IAM experimental. $O$ aumento de capilares pela terapia gênica tem presumível efeito benéfico na redução e recuperação da área isquêmica.

Descritores: Terapia gênica. Angiogênese. VEGF. Infarto do miocárdio

production of fluorescent green protein. In this work we demonstrated an effective protein production in the treated area, and thus, the efficacy of the process of genic transfection of this model.

The objective of this study was to evaluate the reperfusion and the formation of new vessels (capillaries and arterioles) after plasmid VEGF 165 transmural injection in a canine model of acute ischemic heart disease.

\section{METHOD}

\section{Experimental Technique}

To perform this experiment 11 mongrel bitches with weights between 11 and $21 \mathrm{~kg}$ (mean $14.36 \pm 3.13)$ were operated on in the animal experimental laboratory of the Cardiology Institute of Rio Grande do Sul / University Foundation of Cardiology. The handling of the animals followed the norms established by the "Guide for care and use of laboratory animals" of the Institute of Laboratory Animal Resources, National Academy of Sciences, Washington D.C. and by the ethical principles for animal experimentation of the Brazilian Code on Animal Experimentation (COBEA).

The anesthetic procedure was performed using xylazine (1 mg / $5 \mathrm{~kg}$ intramuscular), propofol $(0.5 \mathrm{mg} / \mathrm{kg} \mathrm{EV})$ and fentanyl $(1 \mathrm{ml} / 10 \mathrm{~kg} \mathrm{EV})$. The animals were intubed and the surgical approach of the heart was made by lateral thoracotomy in the fifth left intercostal spacing. To induce myocardial 
infarction, a simple ligature of the main diagonal branch of the anterior ascending coronary artery with 5-0 monofilament polypropylene thread.

The dogs were divided into two groups:

The control group, formed by six dogs that were injected with $1 \mathrm{ml}$ of saline solution split into 10 points in the infarcted area and the peripheral region.

The treated group formed by six dogs that were injected with $200 \mu \mathrm{g}$ of plasmid containing VEGF 165 suspended in 1 $\mathrm{ml}$ of saline solution also divided in ten points in the infarcted area and the peripheral region.

On finishing the procedure, the dogs were recovered and myocardial scintigraphy with Tecnecio was performed. At 14 days from myocardial infarction, the scintigraphic study was repeated. After the dogs were anesthetized and sacrificed for the removal of the heart, which was stored in formal to make the histologic study.

\section{Synthesis of VEGF 165}

The DNA used in this experiment was constructed by the insertion of the VEGF 165 gene in the skeleton of plasmid with eukaryotic pCIS expression supplied by Genentech USA. The plasmid was introduced in competent bacteria XL1-Blue (Stratagene, La Jolla, California) by thermal shock and purification with the use of the DNA preparation kit Maxiprep (Qiagen, Valencia, California) according to the manufacturer's instructions. Doses of 200 milligrams of DNA were resuspended in $1 \mathrm{ml}$ of saline solution with the objective of using it in the experiment.

\section{Histological Analysis and Capillary Count}

For the histological study samples of the transition area (ischemic) whose average size was $2.67 \pm 0.15 \mathrm{~cm}^{2}$ in the control group and $2.44 \pm 0.53 \mathrm{~cm}^{2}$ in the treated group (not significant) were removed. Also a sample of the myocardium from the posterior wall of the left ventricle was evaluated. After, staining with hematoxylin-eosin and Masson's trichrome stain, was made.

Vessels with sizes less than $25 \mu$ were considered to be capillaries, between 25 and $100 \mu$ arterioles and greater than $100 \mu$ arteries [10]

\section{Statistical Analysis}

The data obtained were registered on individual record cards, contingency tables and they were submitted to statistical analysis using student t-test and the chi-squared test. An $\alpha$ of $5 \%$ (p-value $<0.05$ ) was considered as a significant variation

\section{RESULTS}

\section{Myocardial Scintigraphy}

The scintigraphic examination was effective in three of the dogs from the control group and three from the treated group. The immediate control examinations demonstrated moderate to severe hypoperfusion in the antero-lateral-apical zone (Table 1, Figures 1 and 2). These findings are explained by the perfusion area of the occluded coronary artery. The late control examinations demonstrated a recovery rate of 70 to $90 \%$ of the infarcted area, but in some cases there was persistent lateral hypoperfusion (Table 1, Figures 1 and 2).

\begin{tabular}{|c|c|c|c|}
\hline & Dog & $1^{\text {st examination }}$ & $2^{\text {nd }}$ examination \\
\hline \multirow[t]{3}{*}{$\begin{array}{l}\text { Control } \\
\text { Group }\end{array}$} & & $\begin{array}{l}\text { Moderate latero-apical hypoperfusion, } \\
\text { mild septal hypoperfusion }\end{array}$ & $\begin{array}{l}\text { Recovery of } 90 \% \text { of the } \\
\text { infarcted zone }\end{array}$ \\
\hline & 3 & $\begin{array}{l}\text { Severe antero-latero-apical } \\
\text { hypoperfusion }\end{array}$ & $\begin{array}{l}\text { Recovery of } 70-80 \% \text { of } \\
\text { anterior wall }\end{array}$ \\
\hline & 5 & $\begin{array}{l}\text { Severe antero-latero-apical } \\
\text { hypoperfusion }\end{array}$ & $\begin{array}{l}\text { Recovery of } 70 \% \text { high anterior, } \\
50 \% \text { latero-apical }\end{array}$ \\
\hline \multirow[t]{3}{*}{$\begin{array}{l}\text { Treated } \\
\text { Group }\end{array}$} & & $\begin{array}{l}\text { Severa antero-latero-apical } \\
\text { hypoperfusion }\end{array}$ & $\begin{array}{l}\text { Recovery of } 80 \% \text { antero-lateral, } \\
\text { persisting lateral }\end{array}$ \\
\hline & 8 & $\begin{array}{l}\text { Moderate antero-latero-apical } \\
\text { hypoperfusion }\end{array}$ & $\begin{array}{l}\text { Recovery of } 80 \% \text { high anterior } \\
\text { and 50\% latero-apical }\end{array}$ \\
\hline & 9 & Severe antero-latero-apical hypoperfusion & $\begin{array}{l}\text { Recovery of } 90 \% \text { da lesion, } \\
\text { persisting lateral hypoperfusion }\end{array}$ \\
\hline
\end{tabular}

(a)
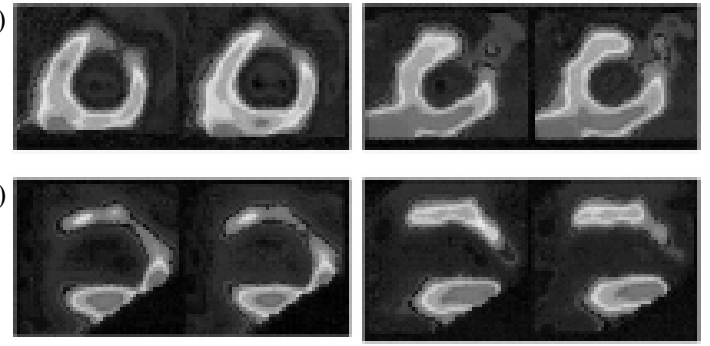

Fig. 1-Myocardial scintigraphy performed in a dog of the control group demonstrating: (a) Severe and extensive antero-latero-apical hypoperfusion in the acute phase, soon after the induction of infarction; (b) Recovery of 70-80\% of the anterior wall with persistence of lateral-apical hypoperfusion 15 days after:

(a)
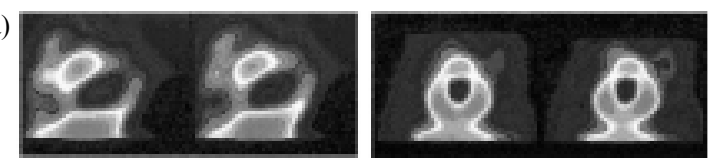

(b)
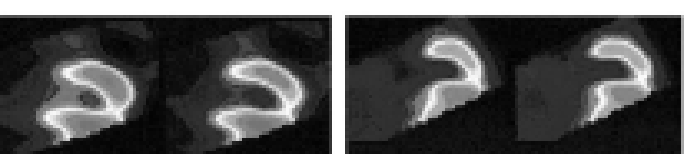

Fig. 2-Myocardial scintigraphy performed in a dog of the treated group demonstrating: (a) severe antero-latero-apical hypoperfusion soon after the induction of infarction; (b) recovery of $90 \%$ of the acute lesion, persisting mild lateral hypoperfusion 15 days after. 
In both the early and late control examinations, no statistical difference evidenced between the control and treated groups, demonstrating the appearance of similar sized infarction zones and with the same pattern of reperfusion.

\section{Anatomicopathological Study}

The pathologic examinations revealed transmural infarction in seven dogs $(63.6 \%)$ and subendocardial infarction in four dogs $(36.3 \%)$, where transmural infarction was considered as that which covered more than $50 \%$ of the wall.

The histological study of the transition area of the acute myocardial infarction (AMI) revealed a greater number of vessels per $\mathrm{cm}^{2}$ in the treated group compared to the control group (mean $123.81 \pm 21.48$ and $40.00 \pm 6.13$ respectively: $p$ value $<0.01$ ). This increase in the number of vessels is mainly attributable to an increment in the number of capillaries $(97.5$ \pm 16.04 in the treated group and $22.18 \pm 3.25$ in the control group: $\mathrm{p}$-value $<0.01$ ). The difference in the increase in the number of arterioles was not significant between the two groups $(25.16 \pm 10.89$ and $17.89 \pm 4.75)$. The comparison between the AMI transition region and the normal myocardial area of the posterior wall of the treated group, showed a greater number of vessels in the treated area, even though the difference was not significant $(123.81 \pm 21.48$ and $95.14 \pm$ 41.19 respectively - Table 2 and figures 3 and 4 ).

Table 2. Histologic study - Comparison between the AMI transition area of the control and treated groups. Data expressed as mean and standard deviation.

\begin{tabular}{lllll}
\hline Group & Vessels per $\mathrm{cm}^{2}$ & $\begin{array}{l}\text { Capillaries } \\
\text { per } \mathrm{cm}^{2}\end{array}$ & $\begin{array}{l}\text { Arterioles } \\
\text { per } \mathrm{cm}^{2}\end{array}$ & $\begin{array}{l}\text { Area removed } \\
\text { as sample }\end{array}$ \\
\hline Control & $40+6.13$ & $22.18+3.25$ & $17.89+4.75$ & $2.58+0.27$ \\
Treated & $123.81+21.48$ & $97.5+16.04$ & $25.16+10.89$ & $2.44+0.53$ \\
Significance & $\mathrm{P}<0.05$ & $\mathrm{P}<0.05$ & $\mathrm{NS}$ & $\mathrm{NS}$ \\
\hline
\end{tabular}

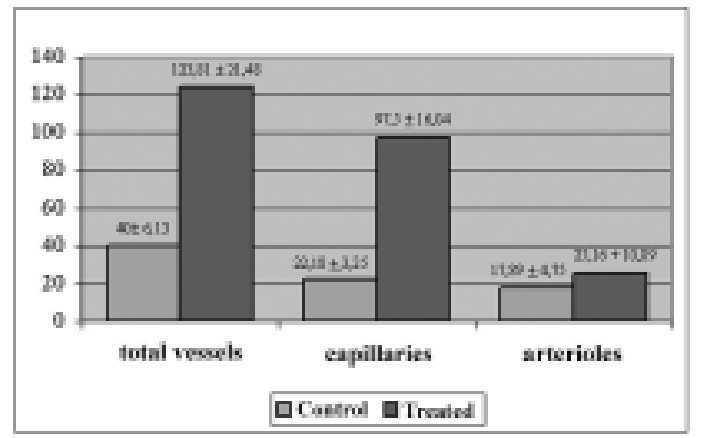

Fig. 3 - Number of vessels per $\mathrm{cm}^{2}$ : Comparison between the control and treated groups.

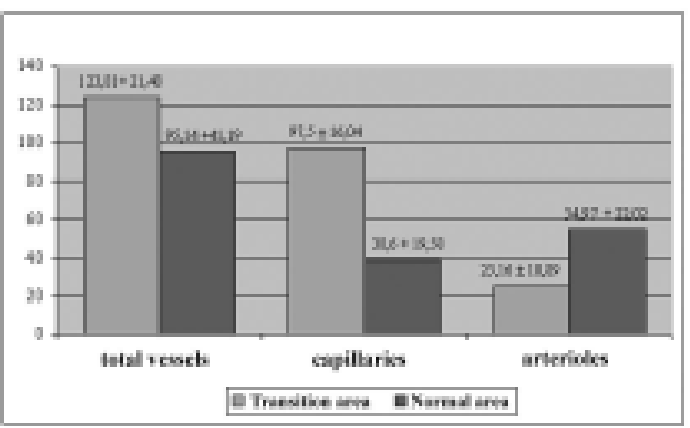

Fig. 4-Number of vessels per $\mathrm{cm}^{2}$ : Comparison between the AMI transition area and of the normal area of the posterior ventricular wall of the treated group.

A statistically significant difference was evidenced in the mean size of the vessels between the control group and the treated group with mean sizes of $27.37 \pm 17.96 \mu$ and $22.08 \pm$ $18.15 \mu$ respectively $(\mathrm{p}$-value $<0.01)$.

\section{DISCUSSION}

The use of recombinant genes and growth factors in the form of recombinant proteins is efficient both as intramural or coronary artery injection. The first, even though it implies thoracotomy, which in the extrapolation from the experimental model to human entails the use of an associated process, gives the advantage of a localized delivery with less systemic leakage. Even so, a study performed with a pericardial injection of FGF (which links to heparin in the same way as VEGF, and thus has a similar distribution) demonstrated through immunohistochemistry that only $19 \%$ of the total injection remains in the myocardium after 150 minutes [11]. Its endovenous use seems limiting, both for "the first elimination in the lung" through low-affinity receptors [12], which limits the percentage of the dose to reach the myocardium [13], as in the already proven hypotensor effect of FGF and VEGF [14-17]. As possible complications of this therapy, the angiogenic factors, as they are implicated in tumoral growth, can accentuate sub-clinical neoplastic processes, or even act in a possible acceleration of the formation of arteriosclerotic lesions and to promote the destabilization of arteriosclerotic plaque $[18,19]$.

The optimum method of evaluating the angiogenesis in the tissue perfusion is not totally clear. Simple angiography is not capable of detecting changes at the microvascular level, but contrast myocardial echocardiography in conjunction with "radio-marked" micro-spheres, was successfully used 
to evaluate the benefits of therapy with VEGF 121 [8]. Studies demonstrated the capacity of VEGF 165 and other angiogenic factors, whether in the form of recombinant proteins or by gene therapy, to generate new vessels in experimental models of ischemic heart disease $[4,10]$.

The most important findings of our study are:

1) In the canine heart, the injection of plasmid containing VEGF 165 in the infarcted area and the peripheral region resulted in a significant increase in the number of capillaries of the treated region in relation to the control group.

2) The neo-vascularization was not capable of determining statistically significant alterations in the myocardial scintigraphy.

The growth of the capillary network, without a significant increase in the number of arterioles, after 15 days, reflects the incapacity of the isolated administration of this angiogenic factor to create a more complete collateral blood flow in the short space of time of this study.

The incapacity of myocardial scintigraphy to demonstrate differences between the groups has complementary explanations: 1) The already referred to incapacity of generating a more consistent collateral blood flow. 2) The limited sensitivity of the examination, in part due to the artifacts generated by our model, such as the size of the biliary vesicula, which retains a significant part of the contrast. 3) The small area of infarction created by the ligature of the main diagonal branch of the anterior descending artery, in conjunction with the recognized facility of the canine myocardium to establish collateral blood flow [10]. This contributes to a total proximal reperfusion in both the groups and made the comparison of the results difficult

In relation to clinical applications of the agents such as VEGF, many questions remain to be answered: 1) Will multiple agents be necessary? 2) Does the agent need to be delivered locally? 3) Is it better to deliver the agent as a recombinant protein or by gene therapy?

Additionally, the most appropriate outcome to evaluate the efficacy of angiogenic therapy is still controversial [8] in part because the ideal method to evaluate the response in terms of blood vessels is not clear. The microvascular level in which the growth factors act is not completely understood, and there are no methods of in vitro imaging to evaluate vessels with diameters of less than $200 \mu$.

In conclusion, the transmural injection of plasmid VEGF 165 resulted in a significant increase in the number of capillaries and in a non-significant increase in the number of arterioles in the experimental AMI transition zone. The increase in the number of capillaries by gene therapy presumably has a beneficial effect in the reduction and recovery of the ischemic area.

\section{BIBLIOGRAPHIC REFERENCES}

1. Kalil RAK. Terapia gênica aplicada à cirurgia cardiovascular Revista da Sociedade de Cardiologia do Rio Grande do Sul 2001; 3: 61-6.

2. Takeshita S, Zheng LP, Brogi E, Kearny M, Pu LQ, Bunting $S$ et al. Therapeutic angiogenesis: a single intraarterial bolus of vascular endothelial growth factor augments revascularization in a rabbit ischemic hind limb model. J Clin Invest 1994;93:662-670.

3. Harada K, Friedman M, Lopez JJ, Wang SY, Li J, Prasad PV et al. Vascular endothelial growth factor administration in chronic myocardial ischemia. Am J Physiol 1996:270:H1791-H1802.

4. Mack CA, Patel SR, Schwartz EA, Janzonico P, Hahn RT, Ilerch et al. Biologic bypass with the use of adenovirusmediated gene transfer of the complementary deoxyribonucleic acid for vascular endothelial growth factor 121 improves myocardial perfusion and function in the ischemic porcine heart. J Thorac Cardiovasc Surg 1998;114:168-177.

5. Banai S, Jacklitsch MT, Shou M, Lazarous DF, Scheinowitz $\mathrm{M}$, Biro S et al. Angiogenic-induced enhancement of collateral blood flow to ischemic myocardium by vascular endothelial growth factors in dogs. Circulation 1994;89:2183-2189.

6. Lee LY, Patel SR, Heckett NR, Mack CA, Polce DR, El-Sawy $\mathrm{T}$ et al. Focal angiogen therapy using intramyocardial delivery of an adenovirus vector coding for vascular endothelial growth factor 121. Ann Thorac Surg 2000; 69:14-24.

7. Henry TD, Abraham JA. Review of preclinical and clinical results with vascular endothelial growth factors for therapeutic angiogenesis. Curr Interv Cardiol Rep. 2000; 2: 228-241.

8. Villanueva FS, Abraham JA, Schreiner GF, Csikari M, Fischer D, Mills JD, et al. Myocardial contrast ecochardiografy can be used to asses the microvascular response to vascular endothelial growth factor-121. Circulation 2002;105:759-65.

9. Kalil RAK, Teixeira LAK, Mastalir ET, Fricke CH, Moreno P, Nardi NB. Experimental model of gene transfection in healthy canine myocardium. Perspectives of gene therapy for ischemic heart disease. Arq Bras Cardiol 2002;79: 228-32.

10. Kawasuji M., Nagamine H, Ikeda M., Sakaribara N, Takemura $\mathrm{H}$, Fujji $\mathrm{S}$ et al. Therapeutic angiogenesis with intramyocardial administration of basic fibroblast growth factor. Ann Thorac Surg 2000;69:1155-61.

11. Lazarous DF, Shou M, Stiber JÁ, Dadhania DM, Thirumurti $\mathrm{V}$, Hodge E et al. Pharmacodinamicous of basic fibroblast growth factor: Pharmacodynamics of basic fibroblast growth factor: route of administration determines myocardial and systemic distribution. Cardiovas Res 1997;37:78-85. 
12. Kornowski R., Fuchs S., Leon MB, Epstein SE. Delivery strategies to achieve therapeutic myocardial angiogenesis. Circulation 2000;101: 454-458.

13. Thirumurti V, Shou M, Hodge E, Goncalves L, Epstein SE, Lazarous DF et al. Lack of efficacy of intravenous basic fibroblast growth factor in promoting myocardial angiogenesis. J Am Coll Cardiol 1998:31:54A. Abstract.

14. Lopez JJ, Edelman ER, Stamler A, Hibberd MG, Prasad P, Thomas KA et al. Angiogenic potential of perivascularly delivered aFGF in a porcine model of chronic myocardial ischemia. Am J Physiol. 1998;274:H930-H936.

15. Lazarous DF, Scheinowitz M, Shou M et al. Effect of chronic systemic administration of basic fibroblast growth factor on collateral development in canine heart. Circulation 1995;91:145-53.
16. Yang R, Thomas GR, Bunting $\mathrm{S}$ et al. Effects of vascular endothelial growth factor on hemodynamics and cardiac performance. J Cardiovasc Pharmacol 1996; 27:838-44.

17. Folkman J. Angiogenic therapy of the human heart. Circulation. 1998;97:628-629.

18. Nabel EG, Yang YZ, Plautz G, Forough R, Zhan X, Maciag T et al . Recombinant fibroblast growth factor-1 promotes intimal hyperplasia and angiogenesis in arteries in vivo. Nature 1993;362:844-46.

19. Inoue $M$, Itoh $H$, Ueda $M$, Naruko T, Kojima M, Komatsu $R$ et al. Vascular endothelial growth factor (VEGF) in human coronary artherosclerotic lesions: possible pathophysiology significance of VEGF in progression of artherosclerotis. Circulation 1998;87:3336-43. 